\title{
Phosphite Inhibits Development of the Nematodes Heterodera avenae and Meloidogyne marylandi in Cereals
}

\author{
Yuji Oka, Nadia Tkachi, and Mishael Mor
}

First and second authors: Nematology Unit, Agricultural Research Organization (ARO), Gilat Research Center, M. P. Negev 85280, Israel; and third author: Department of Entomology and Nematology, ARO, the Volcani Center, Bet Dagan 50250, Israel. Accepted for publication 8 October 2006.

\begin{abstract}
Oka, Y., Tkachi, N., and Mor, M. 2007. Phosphite inhibits development of the nematodes Heterodera avenae and Meloidogyne marylandi in cereals. Phytopathology 97:396-404.

Phosphonic acid $\left(\mathrm{H}_{3} \mathrm{PO}_{3}\right)$ solutions were applied to wheat or to bristle oat as soil drenches before inoculation with juveniles of the sedentary, endoparasitic nematodes Heterodera avenae or Meloidogyne marylandi. All the solutions, which were $\mathrm{pH}$ adjusted and added at levels as low as $0.63 \mathrm{mg}$ of phosphite $\left(\mathrm{HPO}_{3}{ }^{2-}\right)$ per plant, reduced the numbers of $H$. avenae females and M. marylandi egg masses. Phosphate $\left(\mathrm{PO}_{4}{ }^{3-}\right)$, applied as

ber of female nematodes on the wheat. Addition of phosphate to the phosphite solutions did not change the inhibitory effect of phosphite on $H$. avenae, but it reduced phosphite's effect on M. marylandi. Phosphite also reduced the number of $H$. avenae females when applied as many as 20 days after addition of nematodes. The phosphite treatment did not prevent $M$. marylandi juveniles from penetrating wheat roots or inducing giant cells. However, phosphite inhibited giant cell development: 14 days after inoculation, the giant cells in the phosphite-treated wheat were almost completely vacuolated, whereas those in untreated wheat contained dense cytoplasm.
\end{abstract} potassium phosphate at the same concentrations, did not reduce the num-
Several nontoxic compounds are known to inhibit pathogen infection or development in plants (19). When plant responses are involved, this phenomenon is often called induced resistance. Induced resistance to plant pathogens may involve several mechanisms, including the induction of plant chitinases, glucanases, and pathogenesis-related proteins (19). Chemically induced resistance to plant-parasitic nematodes has not been thoroughly studied. DL$\beta$-Amino- $n$-butyric acid (BABA), which induces resistance to several fungal plant pathogens (8), also induces resistance to the root-knot nematode Meloidogyne javanica in tomato, when applied as either a foliar spray or soil drench (26). This resistance was expressed as inhibition of nematode development in tomato roots, probably because of the reduced size and increased vacuolation of the giant cells that supply nutrients to the nematode (26). In a later study, BABA inhibited development of cereal cyst nematodes Heterodera avenae and $H$. latipons on wheat and Meloidogyne spp. on oat when applied as a foliar spray or soil drench (24). However, BABA currently cannot be used for control of these nematodes or fungal diseases because of registration problems.

Species of both Meloidogyne and Heterodera are sedentary endoparasites and have served as model nematodes in studies of host-parasite relationships. The most specific event in the interaction with their hosts is the formation of feeding sites in the roots. Second-stage juveniles (J2) penetrate host roots and induce sophisticated feeding sites by injecting secretions into the root cells (17). Generally, vascular parenchyma cells are chosen for the feeding sites. Although the feeding sites of both nematodes consist of large, mutinucleate, metabolically active cells, those of the cyst nematode are called syncytia and those of the root-knot

Corresponding author: Y. Oka; E-mail address: okayuji@ volcani.agri.gov.il

* The $\boldsymbol{e}$-Xtra logo stands for "electronic extra" and indicates that Figures 1, 2, and 3 appear in color online.

doi:10.1094/PHYTO-97-4-0396

(c) 2007 The American Phytopathological Society nematode are called giant cells. Syncytia develop from the joining of several neighboring cells via cell-wall dissolution plus hypertrophy, whereas giant cells develop from individual cells via hypertrophy and mitosis without cytokinesis (17). The nematodes take nutrients from these cells for their development and maintain the feeding cells by continuous secretion of stimuli via the stylet. In most plants that are resistant to cyst and root-knot nematodes, feeding-site formation is inhibited mainly by a hypersensitive reaction in the host cells or by the early degeneration of the feeding sites (29).

Phosphite ion $\left(\mathrm{HPO}_{3}{ }^{2-}\right)$, the anionic form of phosphonic acid $\left(\mathrm{HPO}(\mathrm{OH})_{2}\right)$, and its metal salts control diseases caused by oomycetes in several plants. The oomycetes include Phytophthora cinnamomi, . citrophthora, $P$. infestans, and Plasmopara viticola (13). Phosphite also controls a wide range of fungal pathogens, such as Fusarium oxysporum and Rhizoctonia solani (13), and several phosphite and phosphonate formulations have been developed and released to the market. Such compounds have controlled Phytophthora cinnamomi in both agricultural crops and natural forests (15). Phosphite controls fungal pathogens through two mechanisms (36): (i) by direct antifungal activity at high concentrations and (ii) by triggering the plant's defense system against pathogens.

In the present study, we tested the ability of phosphite and BABA to control $H$. avenae on wheat and $M$. marylandi on wheat and bristle oat. We also conducted initial experiments to determine how phosphite affects nematodes.

\section{MATERIALS AND METHODS}

Nematode and plant material. $\mathrm{J} 2$ of $H$. avenae pathotype Ha21 (22) were hatched from newly formed, dark-brown cysts collected from a culture maintained on wheat (Triticum aestivum L. cv. Galil) (Hazera Genetics, Israel) (25). M. marylandi J2 were hatched from eggs extracted from bristle oat (Avena strigosa cv. Saia 4) (Hazera Genetics) roots with a sodium hypochlorite solution (16). Hatched $\mathrm{J} 2$ of the cyst and root-knot nematodes were collected daily and stored at 4 and $15^{\circ} \mathrm{C}$, respectively. The $\mathrm{J} 2$ of 
$H$. avenae and $M$. marylandi were less than 14 and 5 days old, respectively, when used in experiments. Wheat cv. Galil and bristle oat cv. Saia 4 were used in all the experiments.

Chemicals. Phosphorous acid $\left(\mathrm{P}(\mathrm{OH})_{3}\right)$ (Sigma-Aldrich, Steinheim, Germany) was dissolved in water at $16 \mathrm{~g} /$ liter to form phosphonic acid. Phosphonic acid is a moderately strong acid ( $\mathrm{p} K_{\mathrm{a} 1}=$ 2.0) and the effect of phosphite was expected to be influenced by $\mathrm{pH}$; therefore, the $\mathrm{pH}$ of the phosphonic acid solution was raised to $5.0,7.0$, or 9.0 with $1 \mathrm{~N}$ solutions of $\mathrm{NaOH}, \mathrm{KOH}$, or $\mathrm{NH}_{4} \mathrm{OH}$. The phosphonic acid solutions were then diluted to a concentration of $8 \mathrm{~g}$ of phosphite $\left(\mathrm{HPO}_{3}{ }^{2-}\right)$ per liter for use as stock solutions. BABA (Sigma-Aldrich, St. Louis) solutions were prepared as previously described (24). The $\mathrm{pH}$ of BABA solutions was not modified because BABA is a week acid $(\mathrm{pH}=6.5)$, and its $\mathrm{pH}$-unmodified solutions controlled several plant pathogens, including nematodes $(8,24,25)$.

Soil drenches with phosphonic acid solutions. Wheat seedlings were grown in 50-ml plastic tubes (one seedling per tube) filled with dune sand at $\mathrm{pH}$ 8.6. When the seedlings were 3 days old, the sand was drenched with 2.5 or $5.0 \mathrm{mg}$ of phosphite per tube in $5 \mathrm{ml}$ of $\mathrm{pH}$-modified phosphate solutions or with a BABA solution at the same doses. The sand of control plants was drenched with $5 \mathrm{ml}$ of tap water. One day after treatment, each seedling was inoculated with $250 \mathrm{H}$. avenae $\mathrm{J} 2$ in $0.3 \mathrm{ml}$ of water and then kept in a growth chamber at $15 \pm 1{ }^{\circ} \mathrm{C}$ with $10 \mathrm{~h}$ of light and $14 \mathrm{~h}$ of dark. The plants were fertilized with a 20-20-20 (N-P$\mathrm{K})$ fertilizer solution every 2 weeks. Adult $H$. avenae females on the roots were counted 2 months after inoculation. Each treatment included five replicates, and the experiment was repeated once.

A similar experiment was done with $M$. marylandi. Three-dayold wheat or bristle oat seedlings were treated with the phosphonic acid solutions as soil drenches, at the same doses as described above. One day after treatment, seedlings were inoculated with $250 \mathrm{M}$. marylandi $\mathrm{J} 2$ in $0.3 \mathrm{ml}$ of water and then kept in a growth chamber at $25 \pm 2{ }^{\circ} \mathrm{C}$ and with $11 \mathrm{~h}$ of light and $13 \mathrm{~h}$ of dark. M. marylandi egg masses on the root systems were stained with $0.015 \%$ phloxine B solution for 15 min and counted 35 days after inoculation. Each treatment included five replicates, and the experiment was repeated once.

Soil drenches with smaller quantities of phosphite. The sand of 3-day-old wheat seedlings grown in the plastic tubes was drenched with $5 \mathrm{ml}$ of phosphonic acid solutions containing 0.63 , 1.25 , or $2.5 \mathrm{mg}$ of phosphite or BABA. The $\mathrm{pH}$ of the phosphonic acid solutions had been adjusted to 5.0 with $\mathrm{KOH}$ or $\mathrm{NH}_{4} \mathrm{OH}$. Control seedlings received $5 \mathrm{ml}$ of water. One day after treatment, the seedlings were inoculated with $250 \mathrm{H}$. avenae $\mathrm{J} 2$ and kept in the growth chamber under the same conditions as described above for the $H$. avenae experiments; the numbers of adult females were recorded 2 months after inoculation. Each treatment included five replicates, and the experiment was repeated once.

A similar experiment was conducted with $M$. marylandi. Wheat seedlings were treated with the phosphonic acid solutions containing $0.63,1.25,2.5$, or $5.0 \mathrm{mg}$ of phosphite and with $\mathrm{pH}$ adjusted to 5.0 with $\mathrm{KOH}$ or $\mathrm{NH}_{4} \mathrm{OH}$. Control seedlings received water. One day after treatment, seedlings were inoculated with $250 \mathrm{M}$. marylandi $\mathrm{J} 2$, and then were kept at $25 \pm 2{ }^{\circ} \mathrm{C}$ and with $11 \mathrm{~h}$ of light and $13 \mathrm{~h}$ of dark. The numbers of $M$. marylandi egg masses on the root systems were counted after staining with the phloxine B solution 35 days after inoculation. Each treatment included five replicates, and the experiment was repeated once.

Direct effect of phosphite on nematodes. One hundred $H$. avenae $\mathrm{J} 2$ were immersed in $0.5 \mathrm{ml}$ of phosphonic acid solution in each well of a 24-well plate (Corning Inc., Corning, NY). The solutions contained phosphite at 0.5 or $1.0 \mathrm{mg} / \mathrm{ml}$, with $\mathrm{pH}$ adjusted to 5.0 by $\mathrm{KOH}$. After $48 \mathrm{~h}$ at $15 \pm 1^{\circ} \mathrm{C}$, the percentages of immobilized nematodes were determined by using a stereomicroscope at a magnification range of $\times 12$ to $\times 25$ (26). The phosphonic acid solutions then were replaced with tap water, and the $\mathrm{J} 2$ from each well were added to a sand-filled tube containing a 3-day-old wheat seedling as described before. The plants were kept in the growth chamber at $15 \pm 1{ }^{\circ} \mathrm{C}, 10 \mathrm{~h}$ of light and $14 \mathrm{~h}$ of dark, and were fertilized every 2 weeks. Females were counted 2 months after inoculation. $\mathrm{J} 2$ that had been immersed in tap water for $48 \mathrm{~h}$ served as controls. There were eight replicates, and the experiment was repeated once.

Phosphonic acid solution sprays. Three-day-old wheat seedlings in plastic tubes each were inoculated with $250 \mathrm{H}$. avenae $\mathrm{J} 2$. Seven days after inoculation, the seedlings were sprayed to runoff with phosphonic acid solutions containing phosphite at $2.0 \mathrm{mg} / \mathrm{ml}$ and with $\mathrm{pH}$ adjusted to 5,7 , or 9 with $\mathrm{NaOH}, \mathrm{KOH}$, or $\mathrm{NH}_{4} \mathrm{OH}$, respectively. Other seedlings were sprayed with water or with a solution containing BABA at $2.0 \mathrm{mg} / \mathrm{ml}$. The solutions and water control also contained the surfactant Extravon (octyphenol-octaglycol ether) (Syngenta, Basel, Switzerland) at $0.5 \mathrm{ml} /$ liter. Soil surfaces in the tubes were covered with filter papers to prevent the solutions from dripping into the soil. The plants were kept at $15 \pm 1{ }^{\circ} \mathrm{C}$ and fertilized every 2 weeks. Females were counted 2 months after inoculation. Each treatment included five replicates, and the experiment was repeated once.

Effect of phosphate. The sand of 3-day-old wheat seedlings grown in the plastic tubes was drenched with $5 \mathrm{ml}$ of solutions containing $5 \mathrm{mg}$ of phosphate $\left(\mathrm{PO}_{4}{ }^{3-}\right.$, a mixture of $\mathrm{K}_{2} \mathrm{HPO}_{4}+$ $\mathrm{KH}_{2} \mathrm{PO}_{4}$ ), $5 \mathrm{mg}$ of phosphite, or $5 \mathrm{mg}$ of phosphate $+5 \mathrm{mg}$ of phosphite. All solutions were applied at $\mathrm{pH}$ levels of 5, 7, and 9. The sand of control plants was drenched with $5 \mathrm{ml}$ of water. The plants were inoculated with $250 \mathrm{H}$. avenae J2 1 day after treatment and kept at $15 \pm 1^{\circ} \mathrm{C}$ with $10 \mathrm{~h}$ of light and $14 \mathrm{~h}$ of dark. The plants were fertilized every 2 weeks, and females were counted 2 months after inoculation. Each treatment included five replicates, and the experiment was repeated once.

An identical experiment was done with $M$. marylandi, except that the plants were kept at $25 \pm 2{ }^{\circ} \mathrm{C}$ with $11 \mathrm{~h}$ of light and $13 \mathrm{~h}$ of dark, and nematode egg masses were counted 35 days after inoculation.

Post inoculation soil drenches. Three-day-old wheat seedlings in the plastic tubes were inoculated with $250 \mathrm{H}$. avenae $\mathrm{J} 2$ per plant and kept in the growth chamber at $15 \pm 1^{\circ} \mathrm{C}$ with $10 \mathrm{~h}$ of light and $14 \mathrm{~h}$ of dark. At 5, 11, 15, and 20 days after inoculation, the soil was drenched with $5 \mathrm{ml}$ of phosphonic acid solutions (containing $5.0 \mathrm{mg}$ of phosphite, with $\mathrm{pH}$ adjusted to 5.0 with $\mathrm{KOH}$ or $\mathrm{NH}_{4} \mathrm{OH}$ ) or with $5.0 \mathrm{mg}$ of BABA dissolved in $5.0 \mathrm{ml}$ of water. Controls received $5 \mathrm{ml}$ of water 5 days after inoculation. The plants were fertilized every 2 weeks and females were counted 2 months after inoculation. Treatments were replicated five times, and the experiment was repeated once.

Nematode penetration. Wheat seedlings were grown in tubes and the sand was drenched with $5 \mathrm{ml}$ of phosphonic acid solutions ( $\mathrm{pH}$ adjusted to 7.0 with $\mathrm{KOH}$ ) at $0,1.25,2.5$, or $5.0 \mathrm{mg}$ of phosphite per seedling. Control plants received $5 \mathrm{ml}$ of water. Each plant was inoculated with $250 \mathrm{M}$. marylandi or $100 \mathrm{H}$. avenae J2 $24 \mathrm{~h}$ after treatment. Six days after inoculation, J2 in the roots were stained with acid fuchsin (4) and counted. Each treatment included five replicates, and the experiment was repeated once.

Nematode development. Three-day-old wheat seedlings grown in the plastic tubes were treated with $5 \mathrm{ml}$ of a phosphonic acid solution ( $\mathrm{pH}$ adjusted to 7.0 with $\mathrm{KOH}$ ) containing $5.0 \mathrm{mg}$ of phosphite, or with a BABA solution at the same concentration; the solutions were applied as soil drenches. Control plants received water. One day after treatment, each seedling was inoculated with $150 \mathrm{~J} 2$ of $H$. avenae or $M$. marylandi. The plants were fertilized every 2 weeks. Nematodes inside the roots were stained with acid fuchsin 7, 14, or 21 days after inoculation. The stained roots were examined with a stereomicroscope at a magnification range of $\times 16$ to $\times 25$, and the presence of $\mathrm{J} 2$, third-stage juveniles (J3), fourth-stage juveniles (J4), syncytia, giant cells, lateral roots, and root hairs was noted. 
Tissue processing for light microscopy. The sand of 3-day-old wheat seedlings grown in the plastic tubes were drenched with $5 \mathrm{ml}$ of water or a phosphonic acid solution (pH adjusted to 5.0 with $\mathrm{KOH}$ ) containing $5.0 \mathrm{mg}$ of phosphite. After $24 \mathrm{~h}$, the seedlings were inoculated with $100 \mathrm{M}$. marylandi $\mathrm{J} 2$ in $0.3 \mathrm{ml}$ of water and then kept at $25 \pm 2{ }^{\circ} \mathrm{C}$ with $11 \mathrm{~h}$ of light and $13 \mathrm{~h}$ of dark. Five plants per treatment were treated and inoculated. Root segments ( $2 \mathrm{~mm}$ long) containing nematodes were cut from the untreated and phosphite-treated plants 7 and 14 days after inoculation. Fixation, dehydration in ethanol, and embedding in Spurr's epoxy resin were as described by Oka et al. (26). Sections $10 \mu \mathrm{m}$ thick were cut with an Ultrotome 2128 ultramicrotome (LKB, Bromma, Sweden) and stained with methylene blue. Five segments were sectioned and examined per treatment. The experiment was repeated once.

Data analysis. Factorial analysis was used to test the significance of the main effects and interactions. The main effects were those of phosphite, phosphate, $\mathrm{pH}$, and hydroxides. The numbers of $H$. avenae females or of $M$. marylandi egg masses were subjected to analysis of variance, and the means were separated according to the Tukey-Kramer highly significant difference test ( $\alpha$ $=0.05$ ). Data presented as percentages were transformed by inverse sine transformation $\left(\sin ^{-1} x\right)$ before data analysis. All calculations were performed with the JMP software (SAS Institute, Cary, NC).

\section{RESULTS}

Soil drench with phosphonic acid solutions. Soil drenches with phosphite at $2.5 \mathrm{mg}$ per wheat plant greatly reduced the numbers of $H$. avenae females (Table 1 ). The effects of $\mathrm{pH}$, hy- droxides, and the interaction of $\mathrm{pH}$ and the phosphite on the number of females were not significant in two trials $(P>0.97,0.10$, and 0.83 , respectively). No adult females were found on plants growing in soil treated with BABA at $2.5 \mathrm{mg}$ per plant.

Soil drenches with the phosphite solutions also reduced the numbers of $M$. marylandi egg masses on wheat or bristle oak seedlings (Table 1). Again, the effects of $\mathrm{pH}$, hydroxides, and the interaction of $\mathrm{pH}$ and the phosphite were not significant $(P>$ $0.20,0.15$, and 0.23 , respectively). There was variation among the treatments in reduction of egg mass number, but not consistently so across the two trials. Treatment with phosphite or BABA did not cause phytotoxicity in the experiments.

Phosphite concentrations. Phosphite at levels as low as $0.63 \mathrm{mg}$ per plant reduced the numbers of $H$. avenae females by $\approx 60 \%$ in trial 1 and $86 \%$ in trial 2 (Table 2). No difference was found between the hydroxides in their effects on the numbers of females. In the first trial and for combined results of both phosphonic acid solutions, the number of females was a negative exponential function of phosphite dose $\left(y=27.19 e^{-0.0057 x} ; R^{2}=\right.$ 0.999). With levels of BABA between 0.63 and $2.5 \mathrm{mg}$ per plant, no females were detected in trial 1 and very few females were detected in trial 2.

Application of phosphite at $0.63 \mathrm{mg} / \mathrm{plant}$ reduced the numbers of M. marylandi egg masses on wheat by 48 to $90 \%$ and on bristle oat by 62 to $87 \%$ (Table 3). The BABA solutions also reduced the number of egg masses on both bristle oat and wheat. Treatment with phosphite or BABA did not cause phytotoxicity in the experiments.

Direct effect of phosphite. $H$. avenae J2 behaved similarly when incubated in water or in the phosphonic acid solutions. Percentages of immobilized $\mathrm{J} 2$ in all the treatments ranged from 6.7

TABLE 1. Numbers of Heterodera avenae females and Meloidogyne marylandi egg masses on host roots as affected by soil drenches with one concentration of pH-modified phosphonic acid solutions or DL- $\beta$-amino- $n$-butyric acid (BABA) ${ }^{\mathrm{x}}$

\begin{tabular}{|c|c|c|c|c|c|c|c|c|c|c|c|c|c|}
\hline \multirow{3}{*}{ Nematode } & \multirow{3}{*}{ Host } & \multirow{3}{*}{ Trial } & \multicolumn{11}{|c|}{ Number of $H$. avenae females or $M$. marylandi egg masses per root ${ }^{y}$} \\
\hline & & & \multirow{2}{*}{ Control } & \multicolumn{9}{|c|}{ Phosphonic acid solution, $\mathrm{pH}$ with } & \multirow{2}{*}{$\mathrm{BABA}^{\mathrm{z}}$} \\
\hline & & & & \multicolumn{3}{|c|}{$\mathrm{NaOH}$} & \multicolumn{3}{|c|}{$\mathrm{KOH}$} & \multicolumn{3}{|c|}{$\mathrm{NH}_{4} \mathrm{OH}$} & \\
\hline H. avenae & Wheat & 1 & $41.2 \mathrm{a}$ & $7.4 \mathrm{~b}$ & $6.4 \mathrm{~b}$ & $6.8 \mathrm{~b}$ & $6.8 \mathrm{~b}$ & $3.2 \mathrm{~b}$ & $8.6 \mathrm{~b}$ & $6.6 \mathrm{~b}$ & $7.8 \mathrm{~b}$ & $1.8 \mathrm{~b}$ & $0 \mathrm{~b}$ \\
\hline H. avenae & Wheat & 2 & $43.8 \mathrm{a}$ & $0.2 \mathrm{~b}$ & $0 \mathrm{~b}$ & $0 \mathrm{~b}$ & $0 \mathrm{~b}$ & $0 \mathrm{~b}$ & $0 \mathrm{~b}$ & $0.2 \mathrm{~b}$ & $0 \mathrm{~b}$ & $0 \mathrm{~b}$ & $0 \mathrm{~b}$ \\
\hline M. marylandi & Wheat & 1 & $48.2 \mathrm{a}$ & $4.4 \mathrm{~d}$ & $6.4 \mathrm{~cd}$ & $6.8 \mathrm{~cd}$ & $28.2 \mathrm{~b}$ & $12.2 \mathrm{~cd}$ & $10.0 \mathrm{~cd}$ & $7.4 \mathrm{~cd}$ & $7.0 \mathrm{~cd}$ & $21.0 \mathrm{bc}$ & nt \\
\hline
\end{tabular}

${ }^{\mathrm{x}}$ Wheat or bristle oat seedlings were treated with a BABA solution (BABA at $2.5 \mathrm{mg} / \mathrm{plant}$ ) or with a phosphonic acid solution $\left(\mathrm{HPO}_{3}{ }^{2-}\right.$ at $\left.2.5 \mathrm{mg} / \mathrm{plant}\right)$. The $\mathrm{pH}$ of the phosphonic acid solution was adjusted with $\mathrm{NaOH}, \mathrm{KOH}$, or $\mathrm{NH}_{4} \mathrm{OH}$, and the solutions were applied as soil drenches to established seedlings. The seedlings were inoculated with $H$. avenae or $M$. marylandi juveniles $24 \mathrm{~h}$ after treatment. Numbers of $H$. avenae adult females and $M$. marylandi egg masses were recorded 2 months and 35 days later, respectively.

y Values are the means of five replicates. Values within a row followed by the same letter do not differ significantly according to the Tukey-Kramer highly significant difference test $(\alpha=0.05)$.

${ }^{\mathrm{z}} \mathrm{nt}=$ not tested.

TABLE 2. Numbers of Heterodera avenae females on wheat roots as affected by soil drenches with different concentrations of pH-modified phosphonic acid solutions or DL- $\beta$-amino- $n$-butyric acid (BABA) $)^{\mathrm{y}}$

\begin{tabular}{|c|c|c|c|c|c|c|c|c|c|c|}
\hline \multirow{3}{*}{$\underline{\text { Trial }}$} & \multicolumn{10}{|c|}{ Number of $H$. avenae females per $\operatorname{root}^{\mathrm{z}}$} \\
\hline & \multirow{2}{*}{ Control } & \multicolumn{6}{|c|}{ Phosphite (mg/plant) } & & & \\
\hline & & \multicolumn{3}{|c|}{ pH 5 with $\mathrm{KOH}$} & \multicolumn{3}{|c|}{ pH 5 with $\mathrm{NH}_{4} \mathrm{OH}$} & \multicolumn{3}{|c|}{ BABA (mg/plant) } \\
\hline 1 & $32.6 \mathrm{a}$ & $15.0 \mathrm{~b}$ & $6.8 \mathrm{~b}-\mathrm{d}$ & $1.4 \mathrm{~d}$ & $12.4 \mathrm{bc}$ & $5.8 \mathrm{~cd}$ & $1.8 \mathrm{~d}$ & $0.4 \mathrm{~d}$ & $0 \mathrm{~d}$ & $0.2 \mathrm{~d}$ \\
\hline 2 & $35.4 \mathrm{a}$ & $5.6 \mathrm{~b}$ & $2.0 \mathrm{~b}$ & $0 \mathrm{~b}$ & $4.4 \mathrm{~b}$ & $2.6 \mathrm{~b}$ & $0 \mathrm{~b}$ & $0 \mathrm{~b}$ & $0 \mathrm{~b}$ & $0 \mathrm{~b}$ \\
\hline
\end{tabular}

${ }_{\mathrm{y}}$ Wheat seedlings were treated with BABA or phosphonic acid solutions containing BABA or $\mathrm{HPO}_{3}{ }^{2-}$ at $0.63,1.25$, or $2.5 \mathrm{mg} / \mathrm{plant}$. The $\mathrm{pH}$ of the phosphonic acid solutions was adjusted by $\mathrm{KOH}$ or $\mathrm{NH}_{4} \mathrm{OH}$ addition, and the solutions were applied as soil drenches to established seedlings. The seedlings were inoculated with $H$. avenae juveniles $24 \mathrm{~h}$ after treatment. Numbers of $H$. avenae adult females were recorded 2 months later.

${ }^{\mathrm{z}}$ Values are the means of five replicates. Values within a row followed by the same letter do not differ significantly according to the Tukey-Kramer highly significant difference test $(\alpha=0.05)$. 
to $10.5 \%$ in trial 1 and from 4.6 to $9.2 \%$ in trial 2 , and no significant difference was found $(P>0.20)$ among the treatments. The number of females on wheat roots inoculated with $\mathrm{J} 2$ that had been immersed in the phosphonic acid solutions or in water ranged from 14.1 to 16.8 per plant in trial 1 and from 21.4 to 23.6 per plant in trial 2 , and no significant difference was found in the numbers among the treatments $(P>0.40)$.

Spray with phosphonic acid solutions. Foliar sprays of phosphonic acid solutions usually reduced the number of $H$. avenae females on wheat roots in the first trial and always reduced the number in the second trial (Table 4). There was no difference between the numbers on phosphite- and on BABA-treated plants. The effects of $\mathrm{pH}$ and hydroxides were not significant $(P>0.13$ and 0.33 ); the interaction between $\mathrm{pH}$ and phosphite also was not significant $(P>0.28)$.

Effect of phosphate. Phosphate applied as a soil drench did not reduce $(P>0.10)$ the numbers of $H$. avenae females or of $M$. marylandi egg masses on wheat, regardless of the solution $\mathrm{pH}$ (Table 5). Numbers of $H$. avenae females were statistically simi- lar on wheat plants treated with phosphonic acid solutions alone or with the mixtures of phosphonic acid and phosphate solutions. There was no significant interaction between phosphite and phosphate $(P=0.27$ and 0.57 in the first and second trials, respectively). In contrast, more $M$. marylandi egg masses occurred on wheat plants treated with the mixtures than on those treated with the phosphonic acid solutions alone. The interaction between phosphite and phosphate was significant $(P<0.0002)$ in the two trials, but the effect of $\mathrm{pH}$ was insignificant $(P>0.05)$.

Post-inoculation soil drench. Two months after nematode inoculation, many $H$. avenae females were recovered from control plants but none were recovered from wheat plants treated with phosphite 5 days after inoculation (Table 6). In the first trial, the numbers of adult females that developed on phosphite-treated plants were $<10 \%$ of the numbers on control plants, even when the treatment was applied 20 days after inoculation. In the second trial, the number of adult females on plants treated with phosphite increased with later application times, but the numbers on treated plants remained substantially smaller than those on controls, even

TABLE 3. Numbers of Meloidogyne marylandi egg masses on host roots as affected by soil drenches with different concentrations of pH-modified phosphonic acid solutions or DL- $\beta$-amino- $n$-butyric acid $(\mathrm{BABA})^{\mathrm{y}}$

\begin{tabular}{|c|c|c|c|c|c|c|c|c|c|c|}
\hline \multirow[b]{3}{*}{ Host plant } & \multirow[b]{3}{*}{ Trial } & \multicolumn{9}{|c|}{ Number of $M$. marylandi egg masses per $\operatorname{root}^{\mathrm{Z}}$} \\
\hline & & \multirow[b]{2}{*}{ Control } & \multicolumn{4}{|c|}{ Phosphite (mg/plant) } & \multicolumn{4}{|c|}{ BABA (mg/plant) } \\
\hline & & & 0.63 & 1.25 & 2.5 & 5.0 & 0.63 & 1.25 & 2.5 & 5.0 \\
\hline Wheat & 1 & $38.6 \mathrm{a}$ & $4.0 \mathrm{~b}$ & $2.4 \mathrm{~b}$ & $2.4 \mathrm{~b}$ & $1.6 \mathrm{~b}$ & $1.4 \mathrm{~b}$ & $0 \mathrm{~b}$ & $0 \mathrm{~b}$ & $0 \mathrm{~b}$ \\
\hline Wheat & 2 & $29.2 \mathrm{a}$ & $15.0 \mathrm{~b}$ & $6.8 \mathrm{c}$ & $3.8 \mathrm{~cd}$ & $1.6 \mathrm{~cd}$ & $7.4 \mathrm{c}$ & $5.0 \mathrm{~cd}$ & $2.8 \mathrm{~cd}$ & $0.4 \mathrm{~d}$ \\
\hline Bristle oat & 1 & $52.4 \mathrm{a}$ & $7.0 \mathrm{bc}$ & $4.8 \mathrm{bc}$ & $3.6 \mathrm{bc}$ & $1.2 \mathrm{c}$ & $9.0 \mathrm{~b}$ & $2.0 \mathrm{bc}$ & $0.2 \mathrm{c}$ & $0.2 \mathrm{c}$ \\
\hline Bristle oat & 2 & $41.7 \mathrm{a}$ & $16.0 \mathrm{~b}$ & $10.1 \mathrm{bcd}$ & $5.0 \mathrm{~cd}$ & $2.7 \mathrm{de}$ & $12.0 \mathrm{bc}$ & $2.0 \mathrm{de}$ & $0 \mathrm{e}$ & $0 \mathrm{e}$ \\
\hline
\end{tabular}

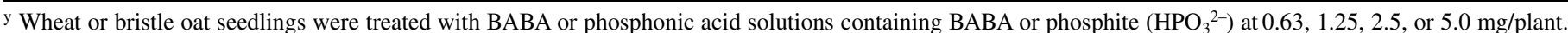
The $\mathrm{pH}$ of the phosphonic acid solution was adjusted to 7 by $\mathrm{KOH}$ addition, and all solutions were applied as soil drenches to established seedlings. The seedlings were inoculated with $M$. marylandi juveniles $24 \mathrm{~h}$ after treatment. Numbers of $M$. marylandi egg masses were recorded 35 days later.

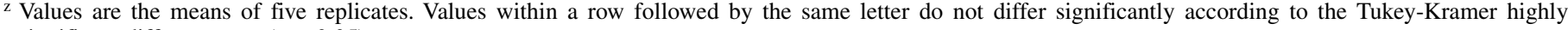
significant difference test $(\alpha=0.05)$.

TABLE 4. Numbers of Heterodera avenae adult females on wheat sprayed with pH-modified phosphonic acid solutions or DL- $\beta$-amino- $n$-butyric acid (BABA) ${ }^{\mathrm{x}}$

\begin{tabular}{|c|c|c|c|c|c|c|c|c|c|c|c|}
\hline \multirow[b]{4}{*}{ Trial } & \multicolumn{11}{|c|}{ Number of $H$. avenae females per $\operatorname{root}^{\mathrm{y}}$} \\
\hline & \multirow[b]{3}{*}{ Control } & \multicolumn{9}{|c|}{ Phosphonic acid ( $\mathrm{pH}$ adjusted to 5,7 , or 9$)^{\mathrm{z}}$} & \multirow[b]{3}{*}{ BABA } \\
\hline & & \multicolumn{3}{|c|}{$\mathrm{NaOH}$} & \multicolumn{3}{|c|}{$\mathrm{KOH}$} & \multicolumn{3}{|c|}{$\mathrm{NH}_{4} \mathrm{OH}$} & \\
\hline & & 5 & 7 & 9 & 5 & 7 & 9 & 5 & 7 & 9 & \\
\hline 1 & $53.4 \mathrm{a}$ & $32.0 \mathrm{~b}$ & $24.2 \mathrm{~b}$ & $35.8 \mathrm{ab}$ & $25.4 \mathrm{~b}$ & $26.4 \mathrm{~b}$ & $35.4 \mathrm{ab}$ & $36.0 \mathrm{ab}$ & $19.8 \mathrm{~b}$ & $24.0 \mathrm{~b}$ & $29.2 \mathrm{~b}$ \\
\hline 2 & $32.8 \mathrm{a}$ & $14.0 \mathrm{~b}$ & $6.4 \mathrm{~b}$ & $14.8 \mathrm{~b}$ & $11.2 \mathrm{~b}$ & $10.0 \mathrm{~b}$ & $9.6 \mathrm{~b}$ & $9.2 \mathrm{~b}$ & $10.8 \mathrm{~b}$ & $12.0 \mathrm{~b}$ & $9.6 \mathrm{~b}$ \\
\hline
\end{tabular}

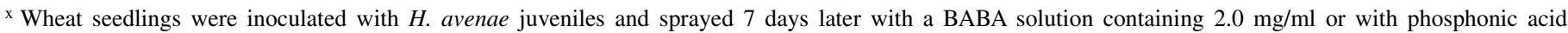
solutions containing $\mathrm{HPO}_{3}{ }^{2-}$ at $2.0 \mathrm{mg} / \mathrm{ml}$. Numbers of adult females were recorded 2 months later.

$\mathrm{y}$ The $\mathrm{pH}$ of the phosphonic acid solutions had been adjusted to 5, 7, or 9 with $\mathrm{NaOH}, \mathrm{KOH}$, or $\mathrm{NH}_{4} \mathrm{OH}$.

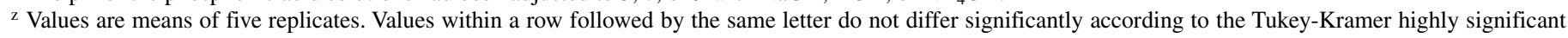
difference test $(\alpha=0.05)$.

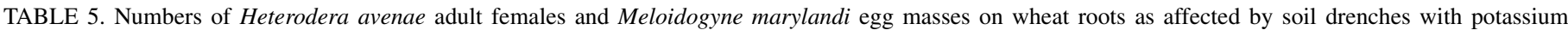
phosphite, $\mathrm{pH}$-modified phosphonic acid solutions, or their mixtures ${ }^{\mathrm{y}}$

\begin{tabular}{|c|c|c|c|c|c|c|c|c|c|c|c|}
\hline \multirow[b]{3}{*}{ Nematode } & \multirow[b]{3}{*}{ Trial } & \multicolumn{10}{|c|}{ Number of $H$. avenae females or $M$. marylandi egg masses per $\operatorname{root}^{\mathrm{z}}$} \\
\hline & & \multirow[b]{2}{*}{ Control } & \multicolumn{3}{|c|}{ Potassium phosphate solution $(\mathrm{pH})$} & \multicolumn{3}{|c|}{ Phosphonic acid solution $(\mathrm{pH})$} & \multicolumn{3}{|c|}{ Mixtures (pH) } \\
\hline & & & 5 & 7 & 9 & 5 & 7 & 9 & 5 & 7 & 9 \\
\hline H. avenae & 1 & $30.8 \mathrm{a}$ & $29.4 \mathrm{a}$ & $30.2 \mathrm{a}$ & $34.3 \mathrm{a}$ & $0.2 \mathrm{~b}$ & $0.2 \mathrm{~b}$ & $1.2 \mathrm{~b}$ & $2.0 \mathrm{~b}$ & $3.8 \mathrm{~b}$ & $4.8 \mathrm{~b}$ \\
\hline H. avenae & 2 & $25.4 \mathrm{a}$ & $31.0 \mathrm{a}$ & $39.4 \mathrm{a}$ & $27.2 \mathrm{a}$ & $0 \mathrm{~b}$ & $0 \mathrm{~b}$ & $0 \mathrm{~b}$ & $1.2 \mathrm{~b}$ & $2.0 \mathrm{~b}$ & $3.2 \mathrm{~b}$ \\
\hline M. marylandi & 1 & $26.0 \mathrm{a}$ & $22.2 \mathrm{ab}$ & $26.4 \mathrm{a}$ & $17.0 \mathrm{ab}$ & $5.8 \mathrm{~cd}$ & $3.6 \mathrm{~d}$ & $1.6 \mathrm{~d}$ & $17.8 \mathrm{ab}$ & $19.3 \mathrm{ab}$ & $14.8 \mathrm{bc}$ \\
\hline M. marylandi & 2 & $32.4 \mathrm{a}$ & $31.8 \mathrm{a}$ & $34.4 \mathrm{a}$ & $33.4 \mathrm{a}$ & $7.4 \mathrm{bc}$ & $4.8 \mathrm{c}$ & $2.6 \mathrm{c}$ & $16.4 \mathrm{~b}$ & $16.8 \mathrm{~b}$ & $12.6 \mathrm{bc}$ \\
\hline
\end{tabular}

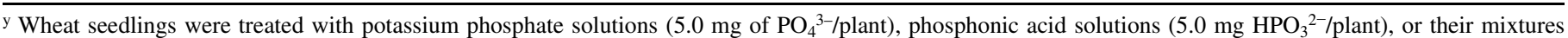
$\left(5.0 \mathrm{mg}\right.$ of $\mathrm{PO}_{4}{ }^{3-}+5.0 \mathrm{mg}$ of $\mathrm{HPO}_{3}{ }^{2-} /$ plant). The $\mathrm{pH}$ of the phosphate and phosphonic acid solutions was adjusted to 5 , 7, or 9 by $\mathrm{KOH}$ addition, and all solutions were applied as soil drenches to established seedlings. The seedlings were inoculated with $H$. avenae or M. marylandi juveniles 24 h after treatment. Numbers of $H$. avenae females and $M$. marylandi egg masses were recorded 2 months and 35 days later, respectively.

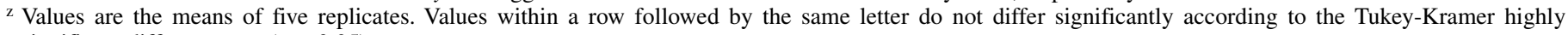
significant difference test $(\alpha=0.05)$. 
when the phosphite was applied 20 days after nematode inoculation $(P<0.001)$. No females developed on BABA-treated plants regardless of application time.

Nematode penetration of roots. The numbers of $M$. marylandi $\mathrm{J} 2$ that penetrated wheat roots ranged from 104 to 140 per plant in trial 1 and from 61 to 69 per plant in trial 2. The numbers were unaffected by drenching soil with phosphite $(P>0.60)$. The numbers of $H$. avenae $\mathrm{J} 2$ that penetrated wheat roots also were unaffected by drenching soil with phosphite $(P>0.30)$ and ranged from 27 to 48 per plant in trial 1 and from 34 to 39 per plant in trial 2.

Nematode development. In control wheat roots, $H$. avenae $\mathrm{J} 2$, $\mathrm{J} 3$, and their syncytia were observed 14 days after inoculation (Fig. 1A); lateral roots and root hairs emerged near the syncytia. In wheat roots treated with the phosphite (Fig. 1B) or BABA (Fig. 1C) solutions, J2 also induced syncytia, and lateral roots emerged near them 14 days after inoculation. In a few cases, cell necrosis was observed near the heads of $\mathrm{J} 2$ in the lateral roots of treated plants. The paths followed by $\mathrm{J} 2$ as they migrated along the central cylinder were stained in the treated plants. By 21 days after inoculation, most $\mathrm{J} 2$ had developed into $\mathrm{J} 3, \mathrm{~J} 4$, or females in the control plants (Fig. 1D), whereas no females or J4 were found in the treated plants (Fig. 1E and F). In both treated (Fig. 1E and F) and untreated roots (Fig. 1D), nematode infection sites supported lateral roots and root hair.

In control wheat roots 7 days after inoculation, most M. marylandi $\mathrm{J} 2$ had developed to $\mathrm{J} 3$ or $\mathrm{J} 4$ (Fig. 2A), and giant cells were observed in the central cylinder of the roots. In plants treated with phosphite (Fig. 2B) or BABA (Fig. 2C) solutions, only a few $\mathrm{J} 2$ had developed to $\mathrm{J} 3$ by day 7 , although giant cells were present. Most of the nematodes in control plants developed into females 14 days after inoculation (Fig. 2D), whereas most of those in phosphite- or BABA-treated plants were $\mathrm{J} 2$ or J3 (Fig. 2E and F).

Light microscopy. $M$. marylandi J2 induced giant cells in the vascular cylinder in both the control and phosphite-treated plants. Seven days after inoculation, the giant cells appeared similar in control plants (Fig. 3A and B) and in phosphite-treated plants (Fig. 3E and F). These giant cells contained more than one nucleus and were filled with small and large vacuoles. At 14 days after inoculation, giant cells in the control plants contained dense cytoplasm and multiple nuclei (Fig. 3C and D). In contrast, the giant cells in the treated plants were fully vacuolated and almost free of organelles at 14 days (Fig. 3G and H). Similar results were observed in two trials.

\section{DISCUSSION}

The present study examined whether $\mathrm{pH}$-adjusted phosphonic acid solutions controlled cyst and root-knot nematodes and whether nematode control was based on induced resistance. Our previous study (24) found that BABA, applied as a soil drench or foliar spray, inhibited development of $H$. avenae and $M$. marylandi on wheat and oat, and the present study used the same nematodes and plants. In other nematode-plant interactions, such as $M$. javanica-tomato, high rates of phosphite (as high as $10 \mathrm{mg}$ per seedling) did not reduce root galling or numbers of nematode eggs (Y. Oka, unpublished data). In the present study, phosphite inhibited the development of both $H$. avenae and $M$. marylandi, regardless of the solution $\mathrm{pH}$ or which hydroxide was used for $\mathrm{pH}$ control.

Our data indicate that the phosphonic acid solutions did not directly affect the nematodes. The solutions did not affect movement of $H$. avenae in vitro. Furthermore, exposure of nematodes to the phosphite solutions for $48 \mathrm{~h}$ did not harm the nematodes; similar numbers of treated and untreated nematodes penetrated wheat roots and developed into adults.

Although the soil-drench treatment of wheat and bristle oat plants with phosphite did not reduce the number of nematodes penetrating the roots, it severely inhibited subsequent nematode development. These results strongly suggest that phosphite inhibits nematode development after feeding sites form. In fact, the postinoculation treatments with phosphite, even at 20 days after inoculation, reduced the number of $H$. avenae adult females. These results indicate that feeding sites of both nematodes in BABA- or phosphite-treated roots did not supply enough nutrients to the nematodes, or that some substance that inhibits nematode development was produced in or moved to the feeding sites. The histological study clearly showed that $M$. marylandi induced giant cells in the phosphite-treated wheat, and no obvious difference between the giant cells in the control roots and those in the treated roots was found at 7 days after inoculation. At 14 days after inoculation, however, the giant cells formed in the treated roots were highly vacuous, and such "empty" giant cells would not sustain nematode development. However, it still is not clear whether the low-density cytoplasm of the giant cells in the treated plants was a direct effect of the phosphite treatment or occurred because the nematodes could not maintain the giant cell activity by stylet secretions. Giant cells with low-density cytoplasm also were observed in tomato roots treated with BABA (24).

We also tested the inhibitory effect of the phosphite on nematode development by spraying the wheat leaves; phosphite is known to be translocated in both the xylem and the phloem $(32,33)$. Phosphite was less effective as a leaf spray than as a soil drench. We do not know whether the phosphite penetrated the leaves and translocated to the roots, but we assume that the chemical did not directly enter the soil because the soil surface was covered. In other studies with radiolabeled BABA, the compound applied on tomato leaves was translocated to actively growing parts, including shoot and root tips (9), and also accumulated in galls and in M. javanica females (27).

Several compounds have been reported to induce resistance against plant-parasitic nematodes or to inhibit parasite development; they include DL-methionine (38) and DL- and L-proline

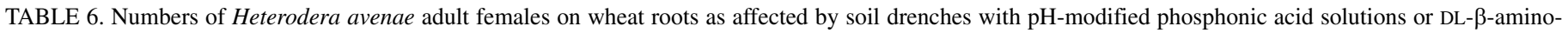
$n$-butyric acid (BABA) 5, 11, 15, or 20 days after inoculation (dai) ${ }^{\mathrm{y}}$

\begin{tabular}{|c|c|c|c|c|c|c|c|c|c|c|c|c|c|}
\hline \multirow[b]{4}{*}{ Trial } & \multicolumn{13}{|c|}{ Number of $H$. avenae females per $\operatorname{root}^{z}$} \\
\hline & \multirow[b]{3}{*}{ Control } & \multicolumn{3}{|c|}{5 dai } & \multicolumn{3}{|c|}{11 dai } & \multicolumn{3}{|c|}{15 dai } & \multicolumn{3}{|c|}{20 dai } \\
\hline & & \multicolumn{2}{|c|}{ Phosphonic acid (pH 5) } & \multirow[b]{2}{*}{ BABA } & \multicolumn{2}{|c|}{ Phosphonic acid (pH 5) } & \multirow[b]{2}{*}{ BABA } & \multicolumn{2}{|c|}{ Phosphonic acid (pH 5) } & \multirow[b]{2}{*}{ BABA } & \multicolumn{2}{|c|}{ Phosphonic acid (pH 5) } & \multirow[b]{2}{*}{ BABA } \\
\hline & & $\mathrm{KOH}$ & $\mathrm{NH}_{4} \mathrm{OH}$ & & $\mathrm{KOH}$ & $\mathrm{NH}_{4} \mathrm{OH}$ & & $\mathrm{KOH}$ & $\mathrm{NH}_{4} \mathrm{OH}$ & & $\mathrm{KOH}$ & $\mathrm{NH}_{4} \mathrm{OH}$ & \\
\hline 1 & $32.6 \mathrm{a}$ & $0 \mathrm{~b}$ & $0 \mathrm{~b}$ & $0 \mathrm{~b}$ & $1.8 \mathrm{~b}$ & $0.6 \mathrm{~b}$ & $0 \mathrm{~b}$ & $1.4 \mathrm{~b}$ & $2.6 \mathrm{~b}$ & $0 \mathrm{~b}$ & $1.4 \mathrm{~b}$ & $2.6 \mathrm{~b}$ & $0 \mathrm{~b}$ \\
\hline 2 & $30.0 \mathrm{a}$ & $0 \mathrm{~d}$ & $0 \mathrm{~d}$ & $0 \mathrm{~d}$ & $5.4 \mathrm{~cd}$ & $2.2 \mathrm{~cd}$ & $0 \mathrm{~d}$ & $9.0 \mathrm{bc}$ & $5.0 \mathrm{~cd}$ & $0 \mathrm{~d}$ & $15.2 \mathrm{~b}$ & $14.4 \mathrm{~b}$ & $0 \mathrm{~d}$ \\
\hline
\end{tabular}

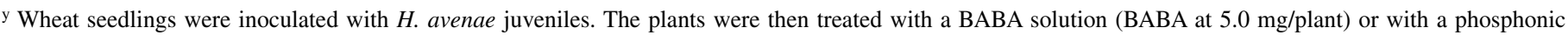
acid solutions $\left(\mathrm{HPO}_{3}{ }^{2-}\right.$ at $5.0 \mathrm{mg} /$ plant $) 5,11,15$, or 20 dai. The $\mathrm{pH}$ of the phosphonic acid solutions was adjusted with $\mathrm{KOH}$ or $\mathrm{NH}_{4} \mathrm{OH}$, and all solutions were applied as soil drenches to established seedlings. Numbers of nematode adult females were recorded 2 months after inoculation.

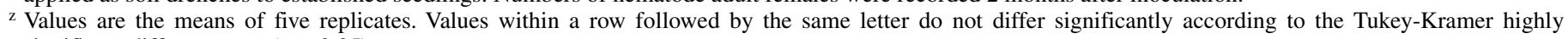
significant difference test $(\alpha=0.05)$. 
(10). The exact mechanism of nematode control by these amino acids has not been determined, but D-amino acids were hypothesized to concentrate near the root tips and, thus, to interfere with nematode nutrition (30). The most studied compounds that can induce resistance in plants against a variety of pathogens are acibenzolar-s-methyl and salicylic acid $(11,19,20)$. Acibenzolar-Smethyl induced resistance to Rotylenchulus reniformis and $M$. javanica in cowpea and pineapple $(6,7)$. Salicylic acid and benzo(1,2,3)thiadiazole-7-carbothioic acid-S-methyl ester (= acibenzolar-S-methyl) applied as a root drench reduced the fecundity of $H$. trifolii and increased the proportions of distorted females (18). In these cases, the resistance was expressed as delayed nematode development and reduced fecundity but not as reduced root penetration. The mode of action of the compounds is unknown.

The mechanism by which phosphite inhibits nematode development differs from the mechanism by which resistant cultivars inhibit nematodes, especially Meloidogyne spp. In Meloidogyne spp.-resistant plants, such as resistant tomato cultivars carrying the $M i$ gene, giant cell formation is rapidly inhibited, presumably by hypersensitive responses, which cause root cell death within 2 days of infection (29). In contrast, in the present study, giant cells were induced by $M$. marylandi and persisted for at least 7 days in the phosphite-treated roots. A similar inhibition of nematode development occurred in the phosphite- or BABA-treated wheat plants infected with $H$. avenae after the induction of syncytia. Further studies will be needed to compare the inhibition of nematode development caused by phosphite or BABA with responses of $H$. avenae-resistant plants in which degradation of the feeding site occurred within 2 to 3 weeks after inoculation (40)

Although the phosphite and BABA inhibited the development of both nematodes, the mechanism of inhibition is not known. BABA-induced resistance in plants against fungal and bacterial pathogens involves callose and lignin deposition, activation of defense mechanisms that depend on phenylpropanoids and the

\section{4 days after inoculation}
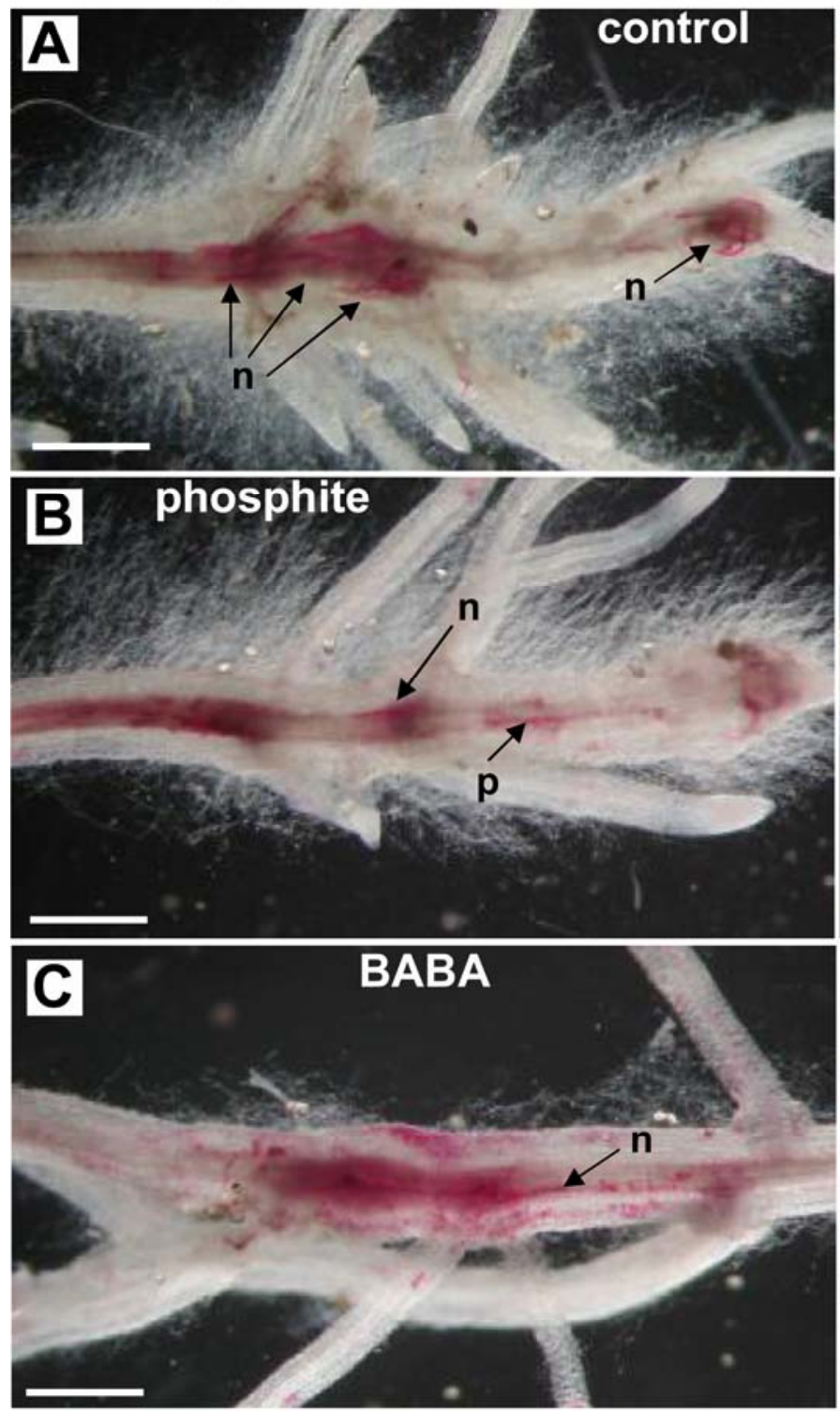

\section{1 days after inoculation}
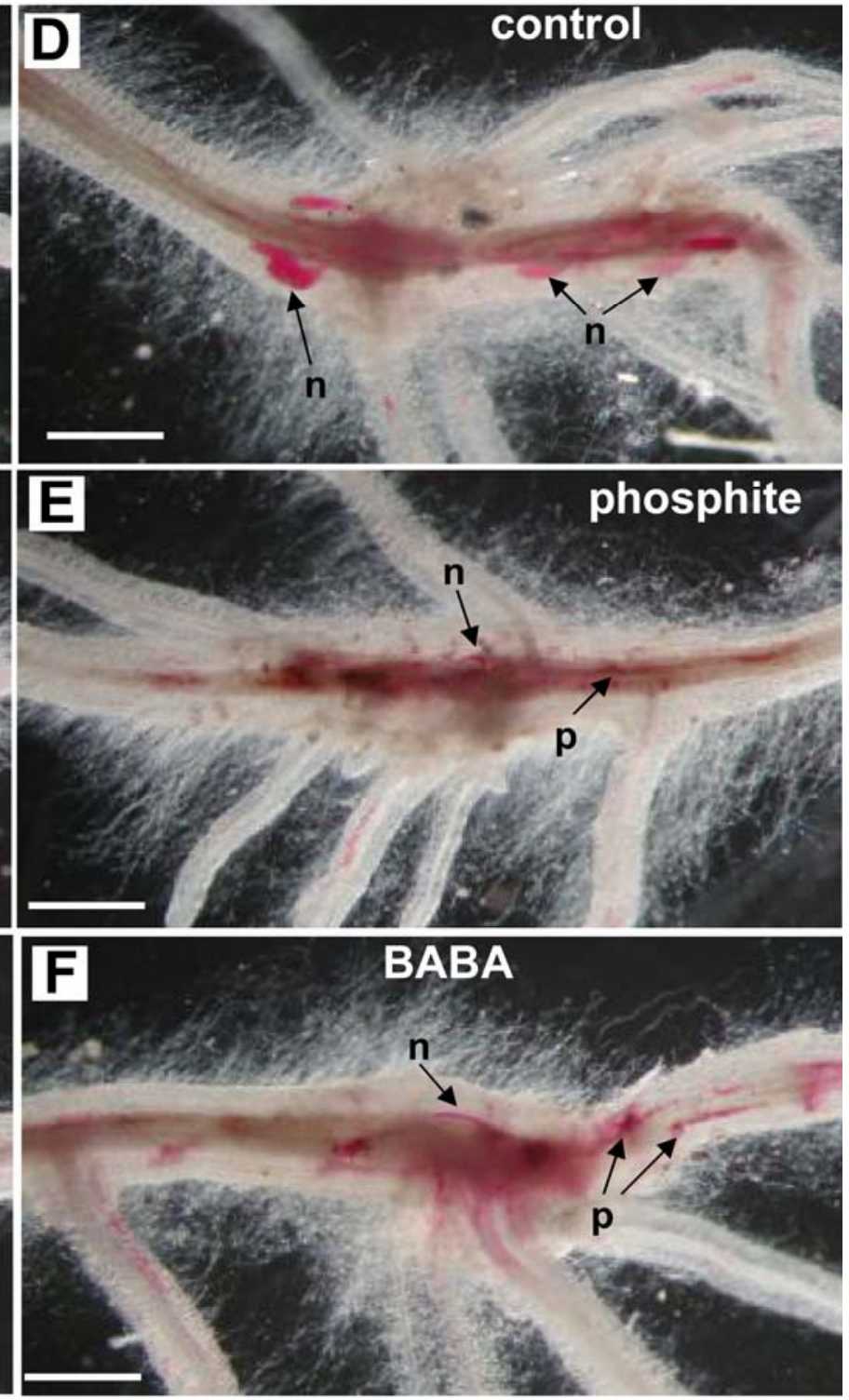

Fig. 1. Effects of soil drenches with phosphite $\left(\mathrm{HPO}_{3}{ }^{2-}\right)$ or DL- $\beta$-amino- $n$-butyric acid (BABA) on development of Heterodera avenae on wheat plants. Wheat seedlings were grown in soil that was drenched with phosphite or BABA solution (5.0 mg per plant). One day after application, each seedling was inoculated with $\approx 150$ second-stage juveniles of $H$. avenae. $\mathbf{A}, \mathbf{B}$, and $\mathbf{C}$, Infection sites 14 days after nematode inoculation; $\mathbf{D}, \mathbf{E}$, and $\mathbf{F}$, infection sites 21 days after nematode inoculation. Infection site of $H$. avenae on $\mathbf{A}$ and $\mathbf{D}$, a control plant, $\mathbf{B}$ and $\mathbf{E}$, a plant treated with phosphite, $\mathbf{C}$ and $\mathbf{F}$, and a plant treated with BABA; $\mathrm{n}=$ nematode, $\mathrm{p}=$ path of nematode movement. Bars $=500 \mu \mathrm{m}$. 
jasmonic acid pathways (14), increased activities of phenylalanine ammonia-lyase and peroxidase, and elevated $\mathrm{H}_{2} \mathrm{O}_{2}$ concentration (2). In plant-fungal pathogen interactions, two mechanisms are involved in the control of pathogens by phosphite: direct fungicidal activity at higher concentrations, and induction of a plant defense response, such as hypersensitive cell death, ethylene biosynthesis, activation of phenylalanine ammonia lyase (PAL), lignification, or phytolexin accumulation (13). Moreover, phenylpropanoid inhibitor and PAL inhibitors reduce phosphite-induced protection $(23,35)$. Most of these responses also have been found in BABA-treated plants, as described above.

Although nematodes exposed to phosphite solutions in vitro developed normally, we cannot rule out the possibility that phosphite directly affected nematodes after they penetrated the roots. Given that phosphonate was persistent in plants, and could be translocated from source to sink similarly to photoassimilates $(31,33)$, nematodes could ingest phosphite via feeding cells. Meloidogyne spp. and Heterodera spp. are nutrient sinks $(3,21)$. Photoassimilates may be translocated to the syncytia of $H$. schachtii in Arabidopsis thaliana via symplastical and apoplastical pathways (37). No information is available on the toxicity of phosphite to nematodes.

Phosphite is known to affect the growth of phosphate-deficient plants. In Brassica nigra, treatment with phosphite decreased intercellular phosphate levels and increased phosphite accumulation 6 times in phosphate-fertilized plants and 16 times in phosphate-deprived plants (5). Moreover, the induction of acid phosphatase and of plasmalemma phosphate translocator was reduced in phosphite-treated plants-responses that resemble the phosphate starvation response of the Brassica plant. In turn, phosphate has appeared to inhibit phosphite uptake in organisms, including plants, by competing for transporter binding site (1). However, phosphite can be used as a phosphorous source for plants after being oxidized to phosphate in soil by microorganisms (13). In our study, no phytotoxicity was caused on the plants by phosphite.

In the present study, we tested the effect of phosphate on the phosphite-induced inhibition of nematode development. The mixtures of mono- and dibasic potassium phosphate solutions, regardless of $\mathrm{pH}$, did not reduce the numbers of $H$. avenae females or M. marylandi egg masses. In addition, phosphate did not reduce the inhibitory effect of phosphite on $H$. avenae development in wheat. The same treatment, however, partly canceled the inhibitory effect of phosphite on $M$. marylandi development on the same plant. We do not know what caused this difference. If phosphate impairs the inhibitory effect of phosphite on nematode development, the use of phosphite for nematode control will be limited in phosphate-rich soils. In the interaction between soilborne pathogens and cereals, phosphorous applied to soil controlled $R$. solani on wheat (39). It is noteworthy that monobasic potassium phosphate $\left(\mathrm{KH}_{2} \mathrm{PO}_{4}\right)$ induces resistance against several fungal pathogens $(12,34)$. Induction of resistance in cucumber by $\mathrm{KH}_{2} \mathrm{PO}_{4}$ involves generation of superoxide and hydrogen peroxide, and increased salicylic acid levels (28).

Our study indicates that phosphite is a potential nematicide for use on gramineous plants, and that its mode of action could be by induced resistance. Phosphite is a relatively safe compound that is permitted in many countries for use as a fertilizer or fungicide,

\section{7 days after inoculation}
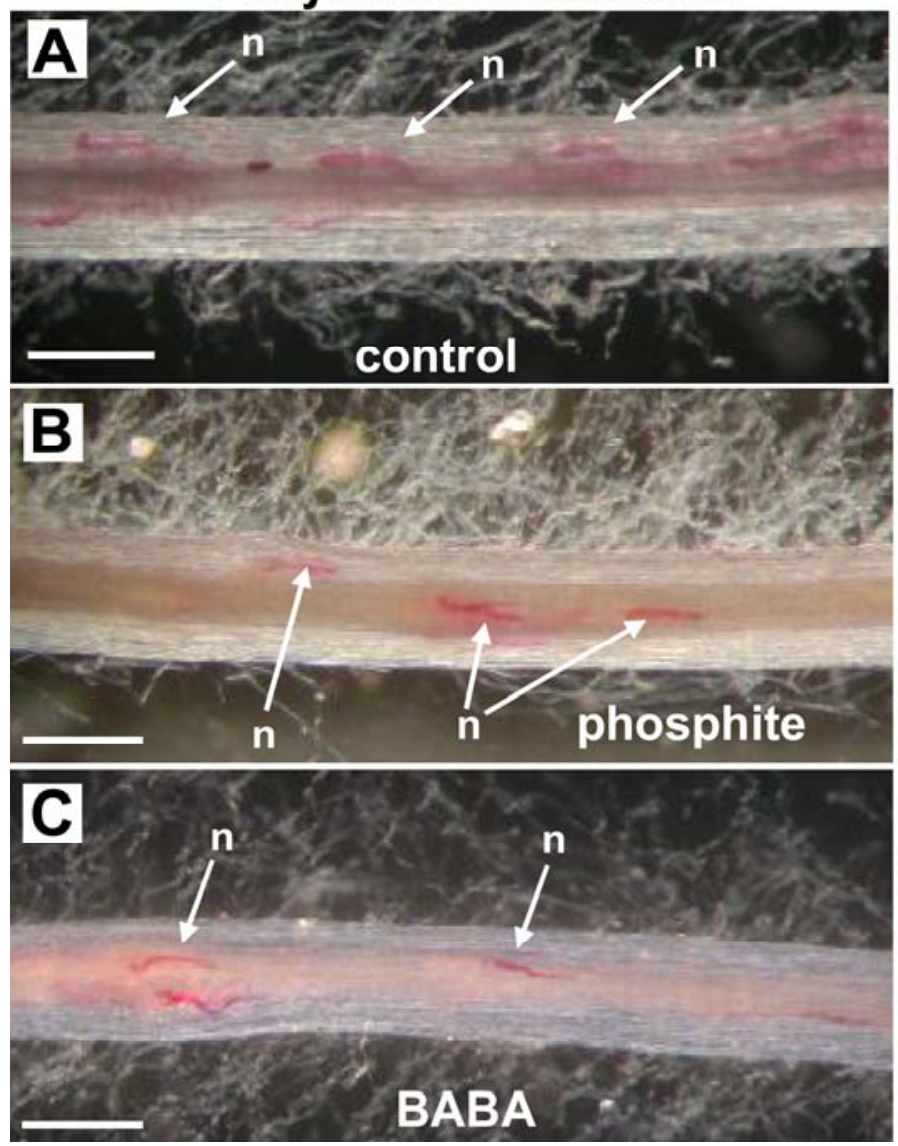

\section{4 days after inoculation}
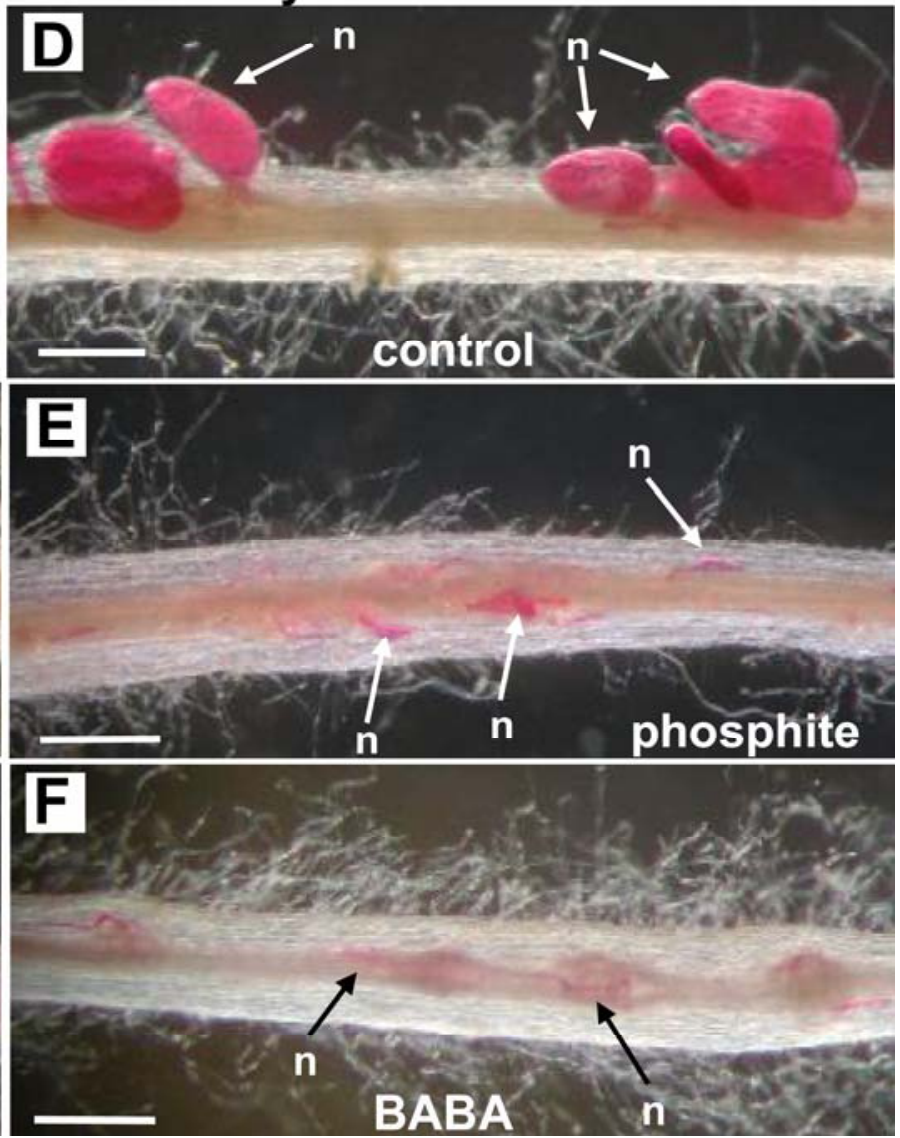

Fig. 2. Effects of soil drenches with phosphite $\left(\mathrm{HPO}_{3}{ }^{2-}\right)$ or DL- $\beta$-amino- $n$-butyric acid (BABA) on development of Meloidogyne marylandi on wheat plants. Wheat seedlings were grown in soil that was drenched with phosphite or BABA solution (5.0 mg per plant). One day after application, each seedling was inoculated with $\approx 150$ second-stage juveniles of $M$. marylandi. A, B, and C, Infection sites 7 days after nematode inoculation; $\mathbf{D}, \mathbf{E}$, and $\mathbf{F}$, infection sites 14 days after nematode inoculation. Infection site of M. marylandi on $\mathbf{A}$ and $\mathbf{D}$, a control plant, $\mathbf{B}$ and $\mathbf{E}$, a plant treated with phosphite, and $\mathbf{C}$ and $\mathbf{F}$, a plant treated with BABA; $\mathrm{n}=$ nematode. Bars $=500 \mu \mathrm{m}$. 


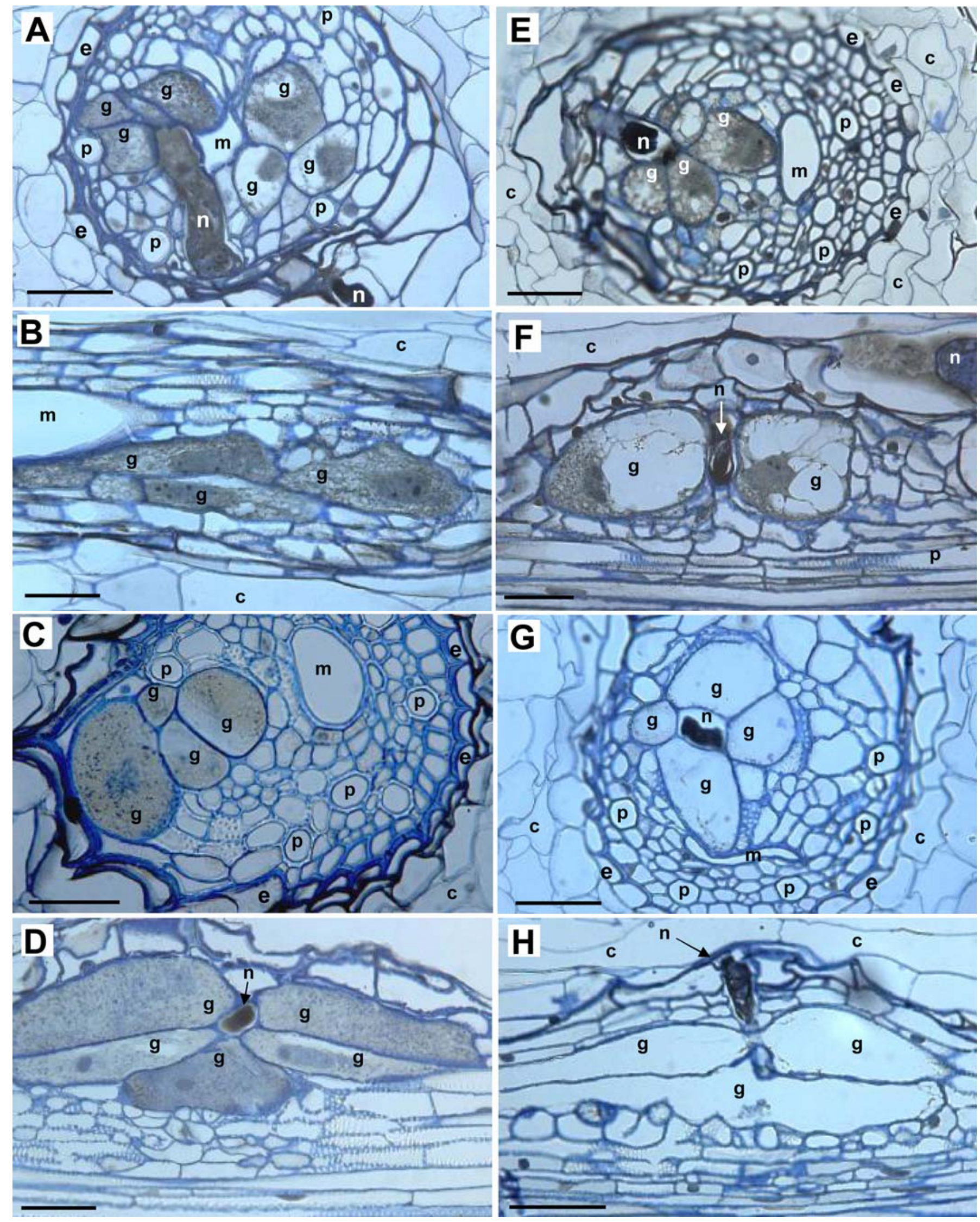

Fig. 3. Light micrographs of Meloidogyne marylandi feeding sites in A to D, untreated and $\mathbf{E}$ to $\mathbf{H}$, phosphite-treated wheat roots. A and E, Cross sections 7 days after inoculation. B and F, Longitudinal sections 7 days after inoculation. $\mathbf{C}$ and $\mathbf{G}$, Cross sections 14 days after inoculation. D and $\mathbf{H}$, Longitudinal sections 14 days after inoculation. Abbreviations: $\mathrm{c}=$ cortical cells, $\mathrm{e}=$ endodermic cells, $\mathrm{n}=$ nematode, $\mathrm{g}=$ giant cell, $\mathrm{m}=$ metaxylem, $\mathrm{p}=$ protoxylem. $\mathrm{Bars}=50 \mu \mathrm{m}$. 
and it costs less than other nematicides. If phosphite can control $H$. avenae at low doses $(1.25 \mathrm{mg} / \mathrm{plant}$, as used in the present study), this compound could be used cost-effectively as a study), this compound could be used cost effectively as a nematicide and a fertilizer, even on low-value crops such as wheat. Further studies, including those that determine how phosphite inhibits nematodes and whether phosphite controls nematodes in the field, are needed to advance this possibility.

\section{LITERATURE CITED}

1. Barchietto, T., Saindrenan, P., and Bompeix, G. 1989. Characterization of phosphonate uptake in two Phytophthora species and its inhibition by phosphate. Arch. Microbiol. 151:54-58.

2. Baysal, O., Gursoy, Y. Z., Ornek, H., and Duru, A. 2005. Induction of oxidants in tomato leaves treated with DL-beta amino butyric acid (BABA) and infected with Clavibacter michiganensis ssp. michiganensis. Eur. J. Plant Pathol. 112:361-369.

3. Böckenhoff, A., Prior, D. A. M., Grundler, F. M. W., and Oparka, K. J. 1996. Induction of phloem unloading in Arabidopsis thaliana roots by the parasitic nematode Heterodera schachtii. Plant Physiol. 112:1421-1427.

4. Byrd, D. W., Kirkpatrick, T., Jr., and Barker, K. R. 1983. An improved technique for clearing and staining plant tissue for detection of nematodes. J. Nematol. 15:142-143.

5. Carswell, M. C., Grant, B. R., Theodorou, M. E., Harris, J., Niere, J. O., and Plaxton, W. D. 1996. The fungicide phosphonate disrupts the phosphate-starvation response in Brassica nigra seedlings. Plant Physiol. 110:105-110.

6. Chinnasri, B., and Sipes, B. S. 2005. Effects of a systemic acquired resistance inducer on nematodes infecting pineapple. Acta Hortic. 666:213-222.

7. Chinnasri, B., Sipes, B. S., and Schmitt, D. P. 2003. Effects of acibenzolar-s-methyl application to Rotylenchulus reniformis and Meloidogyne javanica. J. Nematol. 35:110-114.

8. Cohen, Y. 2002. $\beta$-Amonobutyric acid-induced resistance against plant pathogens. Plant Dis. 86:448-457.

9. Cohen, Y., and Gisi, U. 1994. Systemic translocation of ${ }^{14}$ C-DL-3aminobutyric acid in tomato plants in relation to induced resistance against Phytophthora infestans. Physiol. Mol. Plant Pathol. 45:441-456.

10. Epstein, E. 1972. Effect of pretreatment with some amino acids and amino acid antimetabolites on Longidorus africanus-infected and noninfected Bidens tripartita. Nematologica 18:555-562.

11. Görlach, J., Volrath, S., Knauf-Beiter, G., Hengy, G., Oostendorp, M., Staub, T., Ward, E., Kessmann, H., and Ryals, J. 1996. Benzothiadiazole, a novel class of inducers of systemic acquired resistance, activates gene expression and disease resistance in wheat. Plant Cell 8:629-643.

12. Gottstein, H. D., and Kuc, J. 1989. Induction of systemic resistance to anthracnose in cucumber by phosphates. Phytopathology 79:176-179.

13. Guest, D., and Grant, B. 1991. The complex action of phosphonates as antifungal agents. Biol. Rev. 66:159-187.

14. Hamiduzzaman, M. Md., Jakab, G., Barnavon, L., Neuhaus, J.-M., and Mauch-Mani, B. 2005. $\beta$-Aminobutyric acid-induced resistance against downy mildew in grapevine acts through the potentiation of callose formation and jasmonic acid signaling. Mol. Plant-Microbe Interact. 18:819-829.

15. Hardy, G. E., St. J. Barrett, S., and Shearer, B. L. 2001. The future of phosphite as a fungicide to control the soilborne plant pathogen Phytophthora cinnamomi in natural ecosystems. Aust. Plant Pathol. 30:133-139.

16. Hussey, R. S., and Barker, K. R. 1973. A comparison of methods of collecting inocula of Meloidogyne spp., including a new technique. Plant Dis. Rep. 57:1025-1028.

17. Jones, M. G. K. 1981. Host cell responses to endoparasitic nematode attack: Structure and function of giant cells and syncytia. Ann. Appl. Biol. 97:353372.

18. Kempster, V. N., Davies, K. A., and Scott, E. S. 2001. Chemical and biological induction of resistance to the clover cyst nematode (Heterodera trifolii) in white clover (Trifolium repens). Nematology 3:35-43.

19. Kessmann, H., Staub, T., Hofmann, C., Maetzke, T., Herzog, J., Ward, E., Uknes, S., and Ryals, J. 1994. Induction of systemic acquired disease resistance in plants by chemicals. Annu. Rev. Phytopathol. 32:439-459.

20. Malamy, J., and Klessig, D. F. 1992. Salicylic acid and plant disease resistance. Plant J. 2:643-654.

21. McClure, M. A. 1977. Meloidogyne incognita: A metabolic sink. J. Nematol. 9:88-90.

22. Mor, M., Cohn, E., and Spiegel, Y. 1992. Phenology, pathogenicity and pathotypes of cereal cyst nematodes, Heterodera avenae and H. latipons (Nematoda: Heteroderidae) in Israel. Nematologica 38:494-501.

23. Nemestothy, G. N., and Guest, D. I. 1990. Phytoalexin accumulation, phenylalanine ammonia lyase activity and ethylene biosynthesis in fosetyl-Al treated resistant and susceptible tobacco cultivars infected with Phytophthora nicotianae var. nicotianae. Physiol. Mol. Plant Pathol. 37:207-219

24. Oka, Y., Chet, I., and Spiegel, Y. 1997. Are pathogenesis-related proteins induced by Meloidogyne javanica or Heterodera avenae invasion? J. Nematol. 29:501-508.

25. Oka, Y., and Cohen, Y. 2001. Induced resistance to cyst and root-knot nematodes in cereals by DL- $\beta$-amino- $n$-butyric acid. Eur. J. Plant Pathol. 107:219-227.

26. Oka, Y., Cohen, Y., and Spiegel, Y. 1999. Local and systemic induced resistance to the root-knot nematode in tomato by DL- $\beta$-amino- $n$-butyric acid. Phytopathology 89:1138-1143.

27. Oka, Y., Cohen, Y., and Spiegel, Y. 1999. Induced resistance to plantparasitic nematodes in plants by beta-aminobutyric acid. (Abstr.) J. Nematol. 31:561.

28. Orober, M., Siegrist, J., and Buchenauer, H. 2002. Mechanisms of phosphate-induced disease resistance in cucumber. Eur. J. Plant Pathol. 108:345-353.

29. Paulson, R. E., and Webster, J. M. 1972. Ultrastructure of the hypersensitive reaction in roots of tomato Lycopersicon esculentum L., to infection by the root-knot nematode, Meloidogyne incognita. Physiol. Plant Pathol. 2:227-234.

30. Prasad, S. K., and Webster, J. M. 1967. The effect of amino acid antimetabolites on four nematode species and their host plants. Nematologica 13:318-323.

31. Quimette, D. G., and Coffey, M. D. 1989. Phosphonate levels in avocado seedlings and following treatment with fosetyl-AL or potassium phosphonate. Plant Dis. 73:212-215.

32. Quimette, D. G., and Coffey, M. D. 1989. Comparative antifungal activity of four phosphonate compounds against isolates of nine Phytophthora species. Phytopathology 79:761-767.

33. Quimette, D. G., and Coffey, M. D. 1990. Symplastic entry and phloem translocation of phosphonate. Pestic. Biochem. Physiol. 38:18-25.

34. Reuveni, R., and Reuveni, M. 1998. Foliar-fertilizer therapy-a concept in integrated pest management. Crop Prot. 17:111-118.

35. Saindrenan, P., Barchietto, T., and Bompeix, G. 1998. Modification of the phosphite induced resistance response in leaves of cowpea infected with Phytophthora cryptogea by $\alpha$-aminooxyacetate. Plant Sci. 58:245-252.

36. Smillie, R., Grant, B. R., and Guest, D. 1989. The mode of action of phosphate: Evidence for both direct and indirect modes of action on three Phytophthora spp. in plants. Phytopathology 79:921-926.

37. Stefan, H., Alexander, S., Christian, L., Joachim, S.-S., and Norbert, S. 2005. Nematode infection triggers the de novo formation of unloading phloem that allows macromolecular trafficking of green fluorescent protein into syncytia. Plant Physiol. 138:383-392.

38. Tsai, B. Y., and Van Gundy, S. D. 1988. Effect of DL-methionine on host response to root knot nematodes. (Abstr.) J. Nematol. 20:661-662.

39. Wehner, F. C., Smith, E. M., Barnard, R. O., and Kotze, J. M. 1987. Control of crater disease of wheat, caused by Rhizoctonia solani, using metalaxyl and phosphorous acid. Phytophylactica 19:496-498.

40. Williams, K. J., and Fisher, L. 1993. Development of Heterodera avenae Woll. and host cellular responses in susceptible and resistant wheat. Fundam. Appl. Nematol. 16:417-423. 